Article

\title{
One-Pot Lipase-Catalyzed Enantioselective Synthesis of $(R)-(-)-N$-Benzyl-3-(benzylamino)butanamide: The Effect of Solvent Polarity on Enantioselectivity
}

\author{
Marina A. Ortega-Rojas ${ }^{1}$ (), José Domingo Rivera-Ramírez ${ }^{1}$, C. Gabriela Ávila-Ortiz ${ }^{2}$ (i), \\ Eusebio Juaristi ${ }^{2,3, *} \mathbb{1}$, Fernando González-Muñoz ${ }^{4}$, Edmundo Castillo ${ }^{4, *}$ \\ and Jaime Escalante ${ }^{1, *}$ (iD) \\ 1 The Center for Chemical Research, Autonomous University of Morelos State, Avenida Universidad 1001, \\ Chamilpa, Cuernavaca 62210, Mexico; marina.ortega@uaem.mx (M.A.O.-R.); \\ aghomes315@hotmail.com (J.D.R.-R) \\ 2 Departamento de Química, Centro de Investigación y de Estudios Avanzados, Avenida I.P.N. 2508, \\ Ciudad de México 07360, Mexico; gabriela@relaq.mx \\ 3 El Colegio Nacional, Luis Gonzáles Obregón 23, Centro Histórico, Ciudad de México 06020, Mexico \\ 4 Department of Cell Engineering and Biocatalysis, Institute of Biotechnology, UNAM, Apartado Postal 510-3, \\ Cuernavaca C.P. 62271, Mexico; gonzalez@ibt.unam.mx \\ * Correspondence: juaristi@relaq.mx (E.J.); edmundo@ibt.unam.mx (E.C.); jaime@uaem.mx (J.E.); \\ Tel.: +52-55-5747-3722 (E.J.); +52-77-7311-4903 (E.C.); +52-77-7329-7997 (J.E.)
}

Received: 6 November 2017; Accepted: 4 December 2017; Published: 9 December 2017

\begin{abstract}
The use of the solvent engineering has been applied for controlling the resolution of lipase-catalyzed synthesis of $\beta$-aminoacids via Michael addition reactions. The strategy consisted of the thermodynamic control of products at equilibrium using the lipase CalB as a catalyst. The enzymatic chemo- and enantioselective synthesis of $(R)-(-)$ - $N$-benzyl-3-(benzylamino)butanamide is reported, showing the influence of the solvent on the chemoselectivity of the aza-Michael addition and the subsequent kinetic resolution of the Michael adduct; both processes are catalyzed by CalB and both are influenced by the nature of the solvent medium. This approach allowed us to propose a novel one-pot strategy for the enzymatic synthesis of enantiomerically enriched $\beta$-aminoesters and $\beta$-aminoacids.
\end{abstract}

Keywords: lipase promiscuity; aza-Michael addition; stereoselectivity; enantioselectivity; chemoselectivity; solvent engineering

\section{Introduction}

The synthesis of $\beta$-amino acids and their derivatives is of great interest because these molecules have been shown to have a broad spectrum of biological properties [1-3]. In addition, $\beta$-amino acids are present in numerous natural products of complex molecules [1]. On the other hand, the incorporation of $\beta$-amino acids into $\beta$-peptides gives them structural characteristics capable of resisting hydrolytic degradation for long periods of time [4,5]. As we know, the particular configuration of biologically active $\beta$-amino acids is directly related to their biological activity and therefore to their therapeutic effect, so that the synthesis of these molecules with a certain absolute configuration has been an area of great interest. In this regard, many chemical strategies have been explored for the enantioselective production of $\beta$-amino acids. These methods involve, for example, chiral raw materials in the homologation of natural $\alpha$-amino acids, the use of chiral auxiliaries in asymmetric synthesis, or the resolution of racemic mixtures of $\beta$-amino acids [1,3]. In this context, an alternative to conventional chemical methods for the resolution of racemic mixtures consists in the use of biocatalysts 
in non-aqueous media, a methodology that presents many advantages, including enzymes that show good to high catalytic activity in organic media [6-8]. However, the enzymatic resolution of racemic mixtures usually involves at least two steps, the synthesis of the racemic $\beta$-amino acid followed by enzyme-catalyzed resolution. Among the useful methodologies for the preparation of $\beta$-amino esters is the $a z a$-Michael type addition of amines to $\alpha, \beta$-unsaturated systems employing enzymes such as lipases [9-12].

On the other hand, several useful methodologies to control chemoselectivity in Michael addition have been developed, including the use of mutant enzymes and wild lipases, together with strategies such as solvent engineering $[9,11,13]$. Some authors have investigated different solvents for this type of reaction; however, the use of solvents has not always been intended as a resolutive process [9-12]. The kinetic resolution of racemic amino esters has usually been accomplished by enantioselective substitution reactions in acyl-substituted substrates [14], as well as via the resolution as a substrate for enzymatic $N$-acylation reactions $[15,16]$. Within this context, it has been described that nucleophilic substitution reactions in the acyl group can be achieved by hydrolysis [17], aminolysis [18], and transesterification [19], affording good yields and high enantioselectivity. In this regard, one of the most useful lipases is Candida antarctica lipase B (CalB), which is known for its catalytic promiscuity.

In 2009, our research group reported the successful use of solvent engineering strategies to control the chemoselectivity in the addition of benzylamine (1) to methyl crotonate (2) catalyzed by CalB [9]. In that report it was emphasized that the $a z a$-Michael addition product (4) was preferably accumulated in a hydrophobic medium such as $n$-hexane. The desired $\beta$-amino ester 4 showed a specific rotation of $[\alpha]_{\mathrm{D}}{ }^{20}=+0.45\left(c 1.0, \mathrm{CHCl}_{3}\right)$, whereas the aminolysis product, crotonamide (3), was preferentially accumulated in polar solvents such as 2-methyl-2-butanol (2M2B), and a small amount of 4 obtained showed a specific rotation of $[\alpha]_{\mathrm{D}}{ }^{20}=+11\left(c 1.0, \mathrm{CHCl}_{3}\right)$. No other product was found. At that time, we did not comment on the origin of the observed enantiomeric excess (ee) and why it was achieved only in 2M2B. In that sense, if two reactions such as a nucleophilic addition and a substitution reaction were catalyzed by the same enzyme, one could anticipate that enantiopure esters could be obtained by a one-pot reaction, and that would imply the effect of the polarity of the solvent, not only for the control of the chemoselectivity but also in the enantioselectivity of the reaction, that is, in the resolution process. While the groups of Liese and Gröger reported that the origin of the enantiomeric excess does not result from an enantioselective Michael addition but by an enzymatic resolution via transamidation, their reactions were carried out in the absence of solvents and in a chemoenzymatic two-step process $[18,20,21]$.

Therefore, in this work we carry out a one-pot reaction between benzylamine (1) and methyl crotonate (2) catalyzed by CalB to determine the effect of the polarity of the solvent, particularly its effect on the enantioselectivity of the enzymatic process.

\section{Results and Discussions}

\subsection{Profile of Products Obtained in Solvents of Opposite Polarity: $n$-Hexane and $2 M 2 B$}

Several experiments were carried out to determine how chemo- and enantioselectivity are influenced by the polarity of the reaction medium in the addition reaction of benzylamine 1 to conjugated ester 2 . The experiments were carried out in triplicate in $n$-hexane and 2M2B (two solvents of opposite polarity). Furthermore, a control reaction was carried out in the absence of enzyme. Gas Chromatography-Mass Spectrometry (GC-MS) analysis of crude reaction products in the presence of CalB revealed the formation of the aminolysis product (3), the aza-Michael addition (4), and a double addition (5) (Scheme 1). 

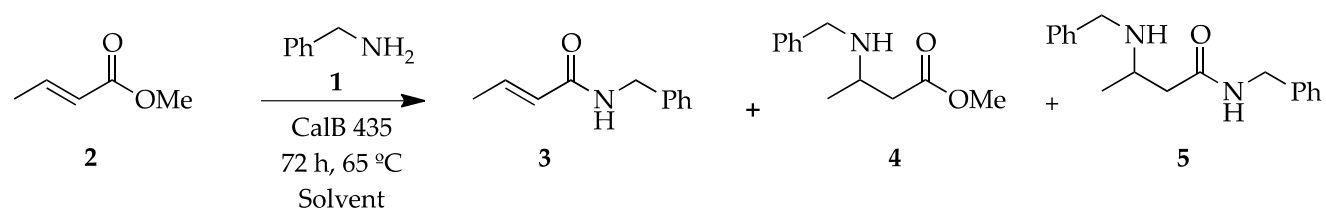

5

Scheme 1. Lipase-catalyzed addition of benzylamine (1) to methyl crotonate (2) to yield aminolysis product (3), aza-Michael addition (4), and double addition product (5).

As shown in Figure 1a, the reaction medium determines the differentiated accumulation of the products. As anticipated, the enzyme is essential for the formation of crotonamide (3), since in the absence of enzyme, $\mathbf{3}$ was not detected (Figure 1b). Interestingly, in the presence of enzyme, $\mathbf{4}$ was preferentially accumulated in $n$-hexane, while in 2M2B the accumulation of 3 was favored. On the other hand, it was observed that $\mathbf{5}$ was formed in both media, although the proportion of $\mathbf{5}$ was slightly higher in 2M2B than in $n$-hexane. Finally, in the control reaction (Figure 1b), the $a z a$-Michael adduct (4) was observed as the main product in the two media. It is noteworthy that the double-addition product (5) accumulated in $n$-hexane but not in 2M2B, so we can conclude that 2M2B is not a suitable solvent for the formation of 5 in the absence of enzyme.<smiles>C/C=C/C(=O)NCc1ccccc1</smiles>

3

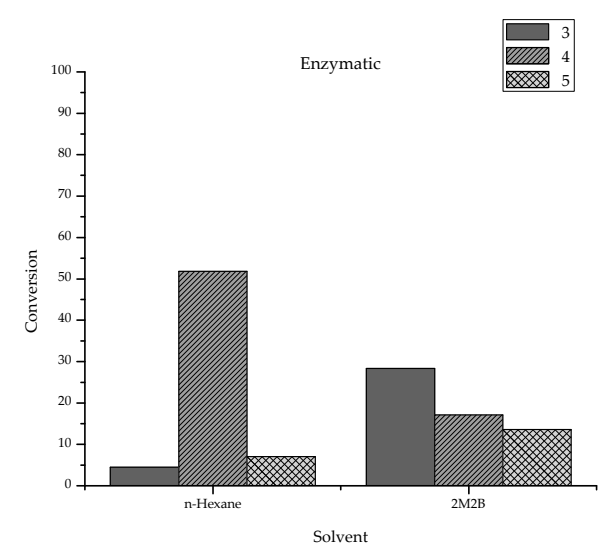

(a)<smiles>COC(=O)CC(C)NCc1ccccc1</smiles>

4<smiles>CC(CC(=O)NCc1ccccc1)NCc1ccccc1</smiles>

Control

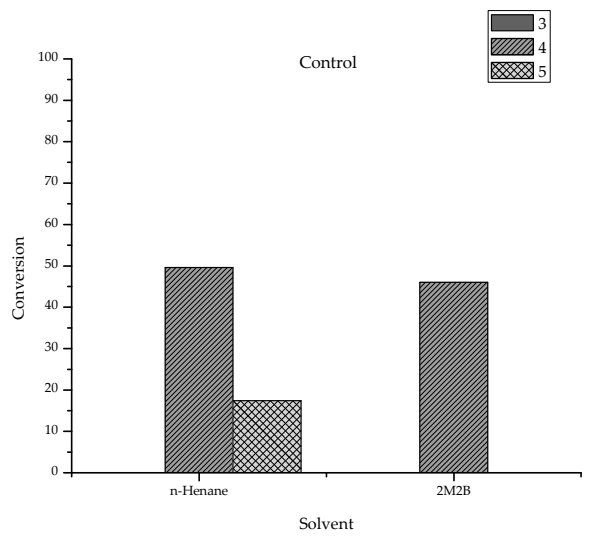

(b)

Figure 1. Influence of the polarity of the solvent in the chemoselective addition of $\mathbf{1}$ to $\mathbf{2}$ :

(a) Lipase-Catalyzed addition; (b) In the absence of enzyme.

\subsection{Enantioselectivity}

As discussed above, in addition to the formation of products 3 and 4 , the double addition product 5 was also detected. With $n$-hexane as the reaction medium 3, 4 , and 5 were obtained in 7,81 , and $12 \%$ yield, respectively. It should be noted that both product 4 and $\mathbf{5}$ presented ee values which were determined by Chiral HPLC. Thus, $\beta$-amino ester 4 exhibited an $e e$ of $1.1 \%\left\{[\alpha]_{\mathrm{D}}{ }^{20}=+0.3\right.$ (c 1.0, $\left.\left.\mathrm{CHCl}_{3}\right)\right\}$ and the $\beta$-aminoamide 5 showed an ee of $3.4 \%\left\{[\alpha]_{\mathrm{D}}{ }^{20}=-1.4\left(c 1.0, \mathrm{CHCl}_{3}\right)\right\}$ (entry 1, Table 1). However, when the medium was $2 \mathrm{M} 2 \mathrm{~B}$, the proportions of 3, 4, and 5 were $48 \%$, 29\%, and $23 \%$, respectively. In contrast to the results obtained in $n$-hexane, the aza-Michael adduct 4 obtained in $2 \mathrm{M} 2 \mathrm{~B}$ showed an $e e$ of $96 \%\left\{[\alpha]_{\mathrm{D}}{ }^{20}=+15.6\left(c 1.0, \mathrm{CHCl}_{3}\right)\right\}$. Finally, the product 5 obtained in 2M2B showed an $e e$ of $72 \%\left\{[\alpha]_{\mathrm{D}}{ }^{20}=-19.2\left(c 1.0, \mathrm{CHCl}_{3}\right)\right\}$ (entry 3, Table 1$)$. These results are consistent with those obtained in our previous report [9]. 
Table 1. Conversion and proportions of 3, 4, and 5 products obtained in the addition of benzylamine $\mathbf{1}$ to methyl crotonate 2 in $n$-hexane and 2M2B.

\begin{tabular}{|c|c|c|c|c|c|c|c|c|}
\hline \multirow[t]{2}{*}{ Entry } & \multirow[t]{2}{*}{ Enzyme } & \multirow[t]{2}{*}{ Solvent } & \multirow[t]{2}{*}{ Conversion $^{a}$} & \multirow[t]{2}{*}{$\begin{array}{c}\text { Proportion }(\%) b \\
3 / 4 / 5\end{array}$} & \multicolumn{2}{|c|}{$\begin{array}{c}\text { 1,4-Addition } \\
4 \\
\end{array}$} & \multicolumn{2}{|c|}{$\begin{array}{c}\text { Double Add } \\
5 \\
\end{array}$} \\
\hline & & & & & {$[\alpha]_{D}{ }^{c}$} & $e e(\%)^{\mathrm{d}}$ & {$[\alpha]_{D}{ }^{c}$} & $e e(\%){ }^{\mathrm{e}}$ \\
\hline 1 & CalB 435 & $n$-hexane, $100 \%$ & 64 & $7 / 81 / 12$ & +0.3 & 1.1 & -1.4 & 3.4 \\
\hline 2 & Control & $n$-hexane, $100 \%$ & 67 & $\mathrm{ND} / 74 / 26$ & 0 & 0 & 0 & 0 \\
\hline 3 & CalB 435 & 2M2B, $100 \%$ & 59 & $48 / 29 / 23$ & +15.6 & 96 & -19.2 & 72 \\
\hline 4 & Control & $2 \mathrm{M} 2 \mathrm{~B}, 100 \%$ & 46 & ND/100/ND & 0 & 0 & 0 & 0 \\
\hline 5 & CalB 435 & $n$-hexane/2M2B, 50:50 & 67 & $48 / 29 / 23$ & +11.6 & 79.8 & -20.8 & 67.8 \\
\hline 6 & Control & $n$-hexane/2M2B, 50:50 & 53 & ND/90/10 & 0 & 0 & 0 & 0 \\
\hline 7 & CalB 435 & $n$-hexane/2M2B, 90:10 & 84 & $25 / 28 / 47$ & +7.7 & 75 & -21 & 67 \\
\hline 8 & Control & $n$-hexane/2M2B, 90:10 & 74 & $\mathrm{ND} / 80 / 20$ & 0 & 0 & 0 & 0 \\
\hline
\end{tabular}

Reaction conditions: $3.5 \mathrm{mmol}$ of benzylamine 1, $1.5 \mathrm{eq}$ of methyl crotonate 2, $70 \mathrm{mg}$ of CalB (Novozyme 435), $0.1 \mathrm{~g}$ of molecular sieves, and $7 \mathrm{~mL}$ of solvent. Conversion was calculated in the basis of 1 consumption. ${ }^{a}$ Yield determined as isolated product. ${ }^{\mathrm{b}}$ Determined as proportion by CG-MS. ${ }^{\mathrm{c}}\left(\mathrm{c} 1.0, \mathrm{CHCl}_{3}\right){ }^{\mathrm{d}}$ ee determined by Chiral HPLC. Chiracel OD-H, hexane/ $i$-PrOH 98:02, $0.8 \mathrm{~mL} \mathrm{~min}^{-1}$, UV-VIS $210 \mathrm{~nm}$. Retention times: (R)-4: $11 \mathrm{~min},(S)-4$ : 13 min. ${ }^{\mathrm{e}}$ ee determined by Chiral-HPLC. CHIRALPAK ${ }^{\circledR}$ AS-H, hexane $/ i-\mathrm{PrOH}$ 80:20. $1 \mathrm{~mL} \mathrm{~min}^{-1}$, UV-VIS $210 \mathrm{~nm}$. Retention times (S)-5: $20.4 \mathrm{~min},(R)-5: 29.4 \mathrm{~min}$.

As shown in Scheme 2, compound 5 could be produced by the aza-Michael addition of benzylamine 1 on substrate 3 (Path 1) or by the nucleophilic substitution of the acyl group on substrate 4 (Path 2). To clarify which of the two routes is correct, the following experiments were carried out.<smiles>C/C=C/C(=O)OC</smiles>

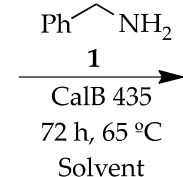

Solvent

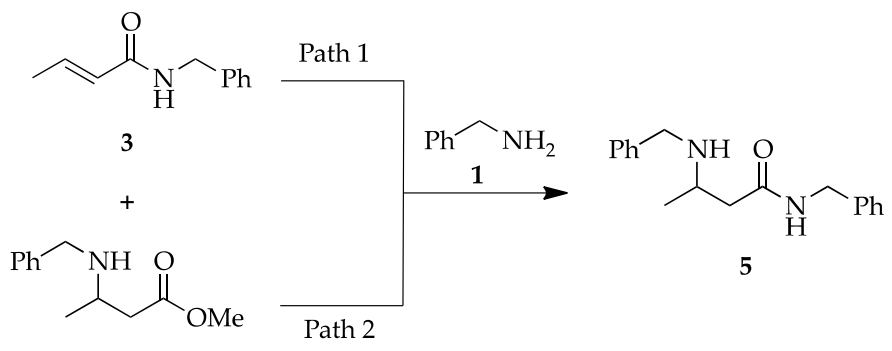

4

Scheme 2. Possible routes for the formation of product 5 by the $a z a$-Michael addition of $\mathbf{1}$ upon the substrate 3 (Path 1), or by the aminolysis process upon the adduct 4 (Path 2).

The first experiment consisted in placing compound $3(0.5 \mathrm{M}$ in $2 \mathrm{M} 2 \mathrm{~B})$ in the presence of CalB $\left(10 \mathrm{mg} \mathrm{mL}^{-1}\right), 0.75$ equiv. of benzylamine $\mathbf{1}$, and 3 Á molecular sieves; this mixture was heated to $65^{\circ} \mathrm{C}$ for $72 \mathrm{~h}$. The enzyme was removed by filtration and washed with dichloromethane (DCM) and the reaction crude was analyzed by thin layer chromatography (TLC) and ${ }^{1} \mathrm{H}-\mathrm{NMR}$, noting that no formation of compound 5 took place.

In a second experiment and after synthesizing rac-4 according to the literature [22], rac-4 was placed in 2M2B $(0.5 \mathrm{M})$ together with benzylamine $1(0.75 \mathrm{eq})$, CalB $\left(10 \mathrm{mg} \mathrm{mL}^{-1}\right)$, and molecular sieves at $65^{\circ} \mathrm{C}$ for $3 \mathrm{~h}$. The crude product from the reaction was analyzed by TLC and ${ }^{1} \mathrm{H}-\mathrm{NMR}$, observing the formation of compound 5 in $41 \%$. The latter result confirms the origin of product 5 by nucleophilic substitution of the acyl group on substrate 4 (Path 2). After the isolation of compound 4 , it showed a specific rotation of $[\alpha]_{\mathrm{D}}{ }^{20}=+7.9\left(c 1.0, \mathrm{CHCl}_{3}\right)$ and for compound 5 of $[\alpha]_{\mathrm{D}}{ }^{20}=-24.5\left(c 1.0, \mathrm{CHCl}_{3}\right)$. This result is also in agreement with the observations made by Gröger and collaborators $[18,20,21]$.

The new results clarify the origin of the enantiomeric excess of the compound $(S)-(+)-4$, obtained in 2M2B, by a resolution process with CalB on the compound rac-4 (Scheme 3). 


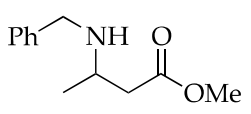

rac -4

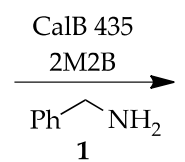

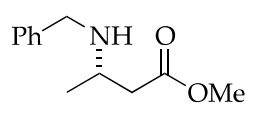

$(S)-(+) 4$

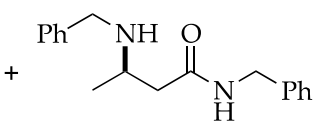

$(R)-(+) 5$

Scheme 3. Resolution of rac-4 in 2M2B with CalB.

To confirm whether the presence of 2M2B played a significant role in the resolution reaction, it was decided to repeat the reaction in a 1:1 mixture of $n$-hexane/2M2B. Under these conditions, the three products 3, 4, and 5 were again found in yields of $48 \%, 29 \%$, and $23 \%$ respectively, and although the proportions did not change with respect to those obtained in $2 \mathrm{M} 2 \mathrm{~B}$, the $e e$ value of the Michael adduct and the double addition product decreased to $79.8 \%$ and $67.8 \%$ respectively (entry 5 , Table 1 ). Additionally, it is important to mention that in the control reaction both the Michael adduct and the double addition product were found in a ratio of 90:10, respectively. These results confirm that 5 is only obtained by an enzymatic process in $2 \mathrm{M} 2 \mathrm{~B}$, since in the control reaction with $2 \mathrm{M} 2 \mathrm{~B}$ this was not observed (entry 4, Table 1). Additionally the low ee of compound 5 obtained in $n$-hexane is probably due to the fact that the chemical process is much faster than the enzymatic process.

\subsection{Optimization of Enantiomeric Excess}

The best values of $e e$ for $(S)-(+)-4$ and $(R)-(-)-5$ were obtained in $100 \%$ of $2 \mathrm{M} 2 \mathrm{~B}$, but this solvent also favors the formation of aminolysis product 3 . Thus, it was decided to design a system in which the formation of 3 could be minimized in order to favor the process of resolution of rac-4. This new system was $n$-hexane/2M2B 90:10. The reaction was monitored by ${ }^{1} \mathrm{H}-\mathrm{NMR}$ and proportions were determined by GC-MS. The products 3, 4, and 5 were found in yields of $25 \%, 28 \%$, and $47 \%$, respectively, and isolated compound 4 showed an $e e$ of $75 \%\left\{[\alpha]_{D}{ }^{20}=+7.7\left(c 1.0, \mathrm{CHCl}_{3}\right)\right\}$. For compound 5 , the ee was $67 \%\left\{[\alpha]_{D}{ }^{20}=-21\left(c 1.0, \mathrm{CHCl}_{3}\right)\right\}$ (entry 7, Table 1). These results were anticipated in terms of the polarity of the solvent, and although the presence of $n$-hexane inhibited the formation of compound 3 , the formation of compound 5 was favored. Also, the optical rotation data were slightly smaller with respect to the reactions carried out in 50:50 of $n$-hexane: 2M2B.

\section{Materials and Methods}

Candida antarctica lipase B (CalB) was obtained as Novozym ${ }^{\circledR} 435$ (Novozymes Mexico, Mexico City, Mexico). Methyl crotonate $\mathbf{2}$ and benzylamine $\mathbf{1}$ were obtained from Sigma Aldrich (St. Louis, MI. USA). Thin layer chromatography (TLC) was carried out on pre-coated Merck silica gel $60 \mathrm{~F}_{254}$ (Merck Mexico, Mexico City, Mexico). Column chromatography was performed on Merck silica gel 60 (0.040-0.063 mm) (Merck Mexico, Mexico City, Mexico). Analytical grade solvents were purchased from Tecsiquim ( $i-\mathrm{PrOH})$ (Tecsiquim, Toluca, Mexico) or Caledon Laboratory Chemicals (n-hexane) (Georgetown, ON, Canada).

\subsection{Analytical Methods}

NMR spectra of products as well as the proportions of each product in the reaction mixture were recorded on Varian Gemini $200 \mathrm{MHz}$ and Varian Mercury $400 \mathrm{MHz}\left({ }^{1} \mathrm{H}-\mathrm{NMR}\right)$, and 50 and $100 \mathrm{MHz}\left({ }^{13} \mathrm{C}-\mathrm{NMR}\right)$ spectrometers, using $\mathrm{CDCl}_{3}$ as a solvent and tretramethylsilane (TMS) as an internal standard. The proportions of each product in the reaction mixture were determine by Gas Chromatography-Mass Spectrometry on an Agilent GC system 6890 series coupled to an Agilent mass selective detector $5973 \mathrm{~N}$ with an HP-5MS column length of $30 \mathrm{~m}$, internal size of $0.25 \mathrm{~mm}$, film thickness of $0.25 \mu \mathrm{m}$, split ration of $5: 1,40{ }^{\circ} \mathrm{C} \min ^{-1}, 5^{\circ} \mathrm{C} \min ^{-1}$ to $250{ }^{\circ} \mathrm{C} \mathrm{min}^{-1}, 10^{\circ} \mathrm{C} \mathrm{min}^{-1}$ to $280^{\circ} \mathrm{C} \mathrm{min}^{-1}$. Retention times ( $\mathrm{min}$ ): $\mathbf{4}=25.3,3=28$, and $\mathbf{5}=43$. Enantiomeric excesses were measured by an HPLC Dionex Ultimate 3000 model and UV Shodex detector RI-101 model at $210 \mathrm{~nm}$, using a Chiracel ${ }^{\circledR}$ OD-H column $(5 \times 250 \mathrm{~mm})$, hexane $/ i$-PrOH $98 / 2(v / v)$ as eluent at a flow rate of 
$0.8 \mathrm{~mL} \mathrm{~min}^{-1}$ at $25^{\circ} \mathrm{C}$ for 4 . Retention times: (R)-4: $11 \mathrm{~min},(S)-4: 13 \mathrm{~min}$. A CHIRALPAK ${ }^{\circledR}$ AS-H column $(5 \times 250 \mathrm{~mm})$ was used for 5 , with hexane $/ i-\mathrm{PrOH} 80 / 20(v / v)$ as eluent at a flow rate of $1 \mathrm{~mL} \min ^{-1}$ at $25{ }^{\circ} \mathrm{C}$. Retention times: (S)-5: $20 \mathrm{~min},(R)-5: 29 \mathrm{~min}$. Optical rotations were measured by means of a Perkin-Elmer 341 polarimeter.

\subsection{Chemistry}

\subsubsection{Enzymatic Reactions}

The enzymatic reactions were carried out in sealed glass vials. The reaction consisted in the preparation of a solution of benzylamine $(0.375 \mathrm{~g}, 3.5 \mathrm{mmol})$, methyl crotonate $(0.525 \mathrm{~g}, 1.5 \mathrm{eq})$, CalB $\left(10 \mathrm{mg} \mathrm{mL}^{-1}\right)$, and $0.01 \mathrm{~g}$ of molecular sieves dissolved in $7 \mathrm{~mL}$ of a pure dry solvent or a solvent mixture. The reaction mixture was stirred in a thermostated water bath at $65{ }^{\circ} \mathrm{C}$ for $72 \mathrm{~h}$. Enzyme was filtered off and washed with DCM and then methanol. The solvent was evaporated under reduced pressure. The proportions of 3, 4, and 5 in the reaction mixture were determined by GC-MS. The products were purified over $\mathrm{SiO}_{2}$ using AcOEt/DCM (98:02 to 60:40) and then AcOEt/MeOH (90:10 to 50:50), and their structures were confirmed by ${ }^{1} \mathrm{H}$ and ${ }^{13} \mathrm{C}-\mathrm{NMR}$, and compared with available information in the literature [21-23].

N-Benzylcrotonamide, (3): White solid, mp 114-116 ${ }^{\circ} \mathrm{C} .{ }^{1} \mathrm{H}-\mathrm{NMR}\left(200 \mathrm{MHz}, \mathrm{CDCl}_{3}\right) \delta 1.83$ (dd, $J=2 \mathrm{~Hz}, J=8 \mathrm{~Hz}, 3 \mathrm{H}) ; 4.47(\mathrm{~d}, J=6 \mathrm{~Hz}, 2 \mathrm{H}) ; 5.82(\mathrm{~m}, 1 \mathrm{H}) ; 5.96$ (br s, $1 \mathrm{H}) ; 6.86$ (m, 1H); 7.21-7.37 (m, 5H). ${ }^{13} \mathrm{C}-\mathrm{NMR}\left(100 \mathrm{MHz}, \mathrm{CDCl}_{3}\right) \delta 17.9,43.7,125.0,127.6,128.0,128.8,138.5,140.4,166.1$. Spectral data ${ }^{1} \mathrm{H}$ and ${ }^{13} \mathrm{C}-\mathrm{NMR}$ are consistent with the literature reports [23].

$(S)-(+)-$ Methyl 3-(benzylamino)butanoate, $[(S)-(+)-4]$ : Yellow oil, after isolation. $[\alpha]_{\mathrm{D}}{ }^{20}=+0.3$ (c 1.0, $\left.\mathrm{CHCl}_{3}\right)$, for product obtained in $n$-hexane; $[\alpha]_{\mathrm{D}}^{20}=+7.7\left(c\right.$ 1.0, $\left.\mathrm{CHCl}_{3}\right)$, for product obtained in $n$-hexane/2M2B, 9:1; $[\alpha]_{\mathrm{D}}{ }^{20}=+11.6\left(c\right.$ 1.0, $\left.\mathrm{CHCl}_{3}\right)$, for product obtained in $n$-hexane/2M2B, 1:1; $[\alpha]_{\mathrm{D}}{ }^{20}=+15.6\left(c\right.$ 1.0, $\left.\mathrm{CHCl}_{3}\right)$, for product obtained in 2M2B. ${ }^{1} \mathrm{H}-\mathrm{NMR}\left(200 \mathrm{MHz}, \mathrm{CDCl}_{3}\right) \delta 1.15$ $(\mathrm{d}, J=8 \mathrm{~Hz}, 3 \mathrm{H}) ; 1.75(\mathrm{br} \mathrm{s}, 1 \mathrm{H}) ; 2.38(\mathrm{dd}, J=16 \mathrm{~Hz}, J=6 \mathrm{~Hz}, 1 \mathrm{H}) ; 2.51(\mathrm{dd}, J=15 \mathrm{~Hz}, J=6 \mathrm{~Hz}, 1 \mathrm{H})$; $3.16(\mathrm{~m}, 1 \mathrm{H}) ; 3.67(\mathrm{~s}, 3 \mathrm{H}) ; 3.74(\mathrm{~d}, J=14,1 \mathrm{H}) ; 3.84(\mathrm{~d}, J=121 \mathrm{H}) ; 7.19-7.41(\mathrm{~m}, 5 \mathrm{H}) .{ }^{13} \mathrm{C}-\mathrm{NMR}(50 \mathrm{MHz}$, $\left.\mathrm{CDCl}_{3}\right) \delta 20.6,41.6,49.9,51.4,51.7,127.1,128.3,128.6,140.5,173.0$. Spectral data ${ }^{1} \mathrm{H}$ and ${ }^{13} \mathrm{C}-\mathrm{NMR}$ are consistent with the literature [22].

$(R)-(-)-N-B e n z y l-3-\left(\right.$ benzylamino)butanamide, $[(R)-(-)-5]$ : Yellow resin, after isolation. $[\alpha]_{\mathrm{D}}{ }^{20}=-1.4$ (c 1.0, $\mathrm{CHCl}_{3}$ ), for product obtained in $n$-hexane; $[\alpha]_{\mathrm{D}}{ }^{20}=-21$ (c 1.0, $\mathrm{CHCl}_{3}$ ), for product obtained in $n$-hexane/2M2B, 9:1; $[\alpha]_{\mathrm{D}}{ }^{20}=-20.8\left(\mathrm{c} 1.0, \mathrm{CHCl}_{3}\right)$, for product obtained in $n$-hexane/2M2B, 1:1; $[\alpha]_{\mathrm{D}}{ }^{20}=-19.2\left(\mathrm{c} 1.0, \mathrm{CHCl}_{3}\right)$, for product obtained in 2M2B. ${ }^{1} \mathrm{H}-\mathrm{NMR}\left(200 \mathrm{MHz}, \mathrm{CDCl}_{3}\right) \delta 1.20$ $(\mathrm{d}, J=8 \mathrm{~Hz}, 3 \mathrm{H}) ; 1.82(\mathrm{br} \mathrm{s}, 1 \mathrm{H}) ; 2.27(\mathrm{dd}, J=16 \mathrm{~Hz}, J=8 \mathrm{~Hz}, 1 \mathrm{H}) ; 2.46(\mathrm{dd}, J=16 \mathrm{~Hz}, J=4 \mathrm{~Hz}, 1 \mathrm{H})$; $3.10(\mathrm{~m}, 1 \mathrm{H}) ; 3.69(\mathrm{~d}, J=12,1 \mathrm{H}) ; 3.80(\mathrm{~d}, J=141 \mathrm{H}) ; 4.42(\mathrm{~d}, J=6,2 \mathrm{H}) ; 7.08-7.37$ (m, 10H); 8.43 (br s, 1H). ${ }^{13} \mathrm{C}-\mathrm{NMR}\left(50 \mathrm{MHz}, \mathrm{CDCl}_{3}\right) \delta 20.3,41.8,43.5,50.4,51.0,127.5,127.5,128.1,128.5,128.8,128.9,138.8$, 171.8. Spectral data ${ }^{1} \mathrm{H}$ are consistent with the literature [21].

\subsubsection{Synthesis of rac-Methyl 3-(benzylamino)butanoate, rac-4 was Prepared According to the Literature}

A solution of benzylamine $(\mathbf{1}, 0.10 \mathrm{~g}, 1 \mathrm{mmol})$ and methyl crotonate $(\mathbf{2}, 0.10 \mathrm{~g}, 1 \mathrm{mmol})$ in $3 \mathrm{~mL}$ of methanol were added to a $10-\mathrm{mL}$ glass microwave reaction vessel containing a stir bar. The reaction vessel was sealed with a cap and then placed into the microwave cavity. The reaction was heated at $\mathrm{T}=150{ }^{\circ} \mathrm{C}$ and $40 \mathrm{psi}$ for $1 \mathrm{~h}$. After the reaction was completed and the vessel was cooled to below $50{ }^{\circ} \mathrm{C}$ using a flow of compressed air, the solvent was evaporated in vacuo and the crude material was purified by column chromatography to give the product as a yellow oil. Yield: $62 \%$. Spectral data ${ }^{1} \mathrm{H}$ and ${ }^{13} \mathrm{C}$ are consistent with those reported in the literature [22].

\section{Conclusions}

In this study, the origin of the ee for $(S)-(+)-4$ obtained in $100 \%$ of $2 \mathrm{M} 2 \mathrm{~B}$ could be clarified as a resolution process on $r a c-4$. First, the addition of benzylamine to methyl crotonate was catalyzed by 
CalB to obtain rac-4, followed by its resolution through an aminolysis reaction to obtain $(R)-(-)-5$. We found that the process in $100 \%$ of $n$-hexane is racemic, and also favors the chemical synthesis of 5. In 2M2B, the synthesis of rac-4 is unfavorable and favors the formation of compound 3. Finally, we found a solvent engineering strategy to control the chemoselectivity in the addition of $a z a-$ Michael catalyzed by CalB and at the same time we demonstrated the direct resolution of an intermediate species through an aminolysis reaction.

Acknowledgments: We would like to thank CONACyT for financial support (Project No. CB2015/256653). Marina A. Ortega-Rojas gratefully acknowledges CONACyT for a scholarship.

Author Contributions: M.A.O.-R., J.D.R.-R., and J.E. conceived and designed the experiments; E.C. performed the experiments; C.G.A.-O., and F.G.-M. analyzed the data by Chiral HPLC; J.E., E.J., and E.C. wrote the paper.

Conflicts of Interest: The authors declare no conflict of interest.

\section{References}

1. Spiteller, P.; von Nussbaum, F. Enantioselective Synthesis of $\beta$-Amino Acids, 2nd ed.; Juaristi, E., Soloshonok, V.A., Eds.; Wiley-VCH: New York, NY, USA, 2005; pp. 19-91. ISBN 978-0-471-46738-0.

2. Ballard, C.E.; Yu, H.; Wang, B. Recent Developments in Depsipeptide Research. Curr. Med. Chem. 2002, 9, 471-498. [CrossRef] [PubMed]

3. Liu, M.; Sibi, M.P. Recent advances in the stereoselective synthesis of $\beta$-amino acids. Tetrahedron 2002, 58, 7991-8035. [CrossRef]

4. Li, X.G.; Kanerva, L.T. Lipases in $\beta$-Dipeptide Synthesis in Organic Solvents. Org. Lett. 2006, 8, 5593-5596. [CrossRef] [PubMed]

5. Steer, D.L.; Lew, R.A.; Perlmutter, P.; Smith, A.I.; Aguilar, M.I. $\beta$-Amino Acids: Versatile Peptidomimetics. Curr. Med. Chem. 2002, 9, 811-822. [CrossRef] [PubMed]

6. Liljeblad, A.; Kanerva, L.T. Biocatalysis as a profound tool in the preparation of highly enantiopure $\beta$-amino acids. Tetrahedron 2006, 62, 5831-5854. [CrossRef]

7. Ghanem, A.; Aboul-Enein, H.Y. Lipase-mediated chiral resolution of racemates in organic solvents. Tetrahedron Asymmetry 2004, 15, 3331-3351. [CrossRef]

8. Zaks, A. New enzymatic properties in organic media. In Enzymatic Reactions in Organic Media, 2nd ed.; Koskinen, A.M.P., Klibanov, A.M., Eds.; Springer: Dordrecht, The Netherlands, 1996; pp. 70-93. ISBN 978-94-011-0611-5.

9. Priego, J.; Ortíz-Nava, C.; Carrillo-Morales, M.; López-Munguía, A.; Escalante, J.; Castillo, E. Solvent engineering: An effective tool to direct chemoselectivity in a lipase-catalyzed Michael addition. Tetrahedron 2009, 65, 536-539. [CrossRef]

10. Steunenberg, P.; Sijm, M.; Zuilhof, H.; Sanders, J.P.M.; Scott, E.L.; Franssen, M.C.R. Lipase-Catalyzed Aza-Michael Reaction on Acrylate Derivatives. J. Org. Chem. 2013, 78, 3802-3813. [CrossRef] [PubMed]

11. Rivera-Ramírez, J.D.; Escalante, J.; Lopez-Murguía, A.; Marty, A.; Castillo, E. Thermodynamically controlled chemoselectivity in lipase-catalyzed aza-Michael additions. Mol. Catal. B Enzym. 2015, 112, 76-82. [CrossRef]

12. Dhake, K.P.; Tambade, P.J.; Singhal, R.S.; Bhanage, B.M. Promiscuous Candida antarctica lipase B-catalyzed synthesis of $\beta$-amino esters via aza-Michael addition of amines to acrylates. Tetrahedron Lett. 2010, 51, 4455-4458. [CrossRef]

13. Carlqvist, P.; Svedendahl, M.; Branneby, C.; Hult, K.; Brinck, T.; Berglund, P. Exploring the Active-Site of a Rationally Redesigned Lipase for Catalysis of Michael-Type Additions. ChemBioChem 2005, 6, 331-336. [CrossRef] [PubMed]

14. Nagy, B.; Galla, Z.; Bencze, L.C.; Toșa, M.I.; Paizs, C.; Forró, E.; Fülöp, F. Covalently Immobilized Lipases are Efficient Stereoselective Catalysts for the Kinetic Resolution of rac-(5-Phenylfuran-2-yl)- $\beta$-alanine Ethyl Ester Hydrochlorides. Eur. J. Org. Chem. 2017, 20, 2878-2882. [CrossRef]

15. Sanchez, V.M.; Rebolledo, F.; Gotor, V. Candida antarctica lipase catalyzed resolution of ethyl ( \pm )-3- aminobutyrate. Tetrahedron Asymmetry 1997, 8, 37-40. [CrossRef]

16. Fitz, M.; Forró, E.; Vigóczki, E.; Lázár, L.; Fülöp, F. Lipase-catalysed $N$-acylation of $\beta^{2}$-amino esters. Tetrahedron Asymmetry 2008, 19, 1114-1119. [CrossRef] 
17. Rangel, H.; Carrillo-Morales, M.; Galindo, J.M.; Obregón-Zúñiga, A.; Juaristi, E.; Escalante, J. Structural features of $N$-benzylated- $\beta$-amino acid methyl esters essential for enantiodifferentiation by lipase B from Candida antarctica in hydrolytic reactions. Tetrahedron Asymmetry 2015, 26, 325-332. [CrossRef]

18. Wei $\beta$, M.; Gröger, H. Practical, Highly Enantioselective Chemoenzymatic One-Pot Synthesis of Short-Chain Aliphatic $\beta$-Amino Acid Esters. Synlett 2009, 8, 1251-1254. [CrossRef]

19. Flores-Sánchez, P.; Escalante, J.; Castillo, E. Enzymatic resolution of $N$-protected- $\beta^{3}$-amino methyl esters, using lipase B from Candida antarctica. Tetrahedron Asymmetry 2005, 16, 629-634. [CrossRef]

20. Strompen, S.; Weiss, M.; Gröger, H.; Hilterhaus, L.; Liese, A. Development of a Continuously Operating Process for the Enantioselective Synthesis of a $\beta$-Amino Acid Ester via a Solvent-Free Chemoenzymatic Reaction Sequence. Adv. Synth. Catal. 2013, 355, 2391-2399. [CrossRef]

21. Strompen, S.; Wei $\beta$, M.; Ingram, T.; Smirnova, I.; Gröger, H.; Hilterhaus, L.; Liese, A. Kinetic Investigation of a Solvent-Free, Chemoenzymatic Reaction Sequence Towards Enantioselective Synthesis of a $\beta$-Amino Acid Ester. Biotechnol. Bioeng. 2012, 109, 1479-1489. [CrossRef] [PubMed]

22. Escalante, J.; Carrillo-Morales, M.; Linzaga, I. Michael Additions of Amines to Methyl Acrylates Promoted by Microwave Irradiation. Molecules 2008, 13, 340-347. [CrossRef] [PubMed]

23. Puertas, S.; Brieva, R.; Rebolledo, F.; Gotor, V. Lipase Catalyzed Aminolysis of Ethyl Propiolate and Acrylic Esters. Synthesis of Chiral Acrylamides. Tetrahedron 1993, 49, 4007-4014. [CrossRef]

Sample Availability: Small samples (a few milligrams) of 3, 4 and 5 are available for the authors. 